\title{
ANALISIS SITUASI PENGGUNAAN GOOGLE CLASSROOM PADA PEMBELAJARAN DARING FISIKA
}

\author{
Maya Mahitsa Agung Mahardini \\ SMAN 1 Pedes, Kabupaten Karawang \\ Email: mayamahitsa@gmail.com
}

Diterima: 1 September 2020 Disetujui: 22 September 2020

\begin{abstract}
Abstrak
Fokus penelitian ini yaitu situasi pembelajaran daring Fisika dengan menggunakan Google Classroom. Desain penelitian yang digunakan adalah kualitatif deskriptif. Responden dalam penelitian ini yaitu peserta didik dan Guru Mata Pelajaran Fisika di SMAN 1 Pedes. Teknik pengumpulan data meliputi wawancara, dan observasi. Teknik analisis yaitu reduksi data, display data dan penarikan kesimpulan. Hasil penelitian menunjukkan perubahan metode pembelajaran fisika konvensional berupa tatap muka antara guru dengan peserta didik di kelas yang dilakukan dengan pemaparan materi, diskusi, tanya jawab ataupun praktikum menjadi metode daring menggunakan Google Classroom mempunyai kelebihan dan kekurangan yang dirasakan oleh guru maupun peserta didik. Kelebihannya diantaranya guru dapat menggunakan berbagai media untuk proses pembelajaran, baik yang terdapat dalam Google Classroom atau media lain yang bisa ditautkan pada classroom tersebut. Sedangkan kekurangannya yaitu permasalahan jaringan maupun keterbatasan kuota yang dimiliki peserta didik bisa menjadi penghambat dalam proses pembelajaran, pun begitu pula dengan rendahnya tingkat keaktifan peserta didik dalam proses pembelajaran. Selain itu, guru merasakan adanya kesulitan untuk menjelaskan materi yang terdapat persamaan-persamaan fisika, peserta didik pun mengalami kesulitan dalam memahami materi tersebut yang berdampak pada rendahnya kemampuan peserta didik menyelesaikan soal hitungan.
\end{abstract}

Kata Kunci: : Pembelajaran Daring, Pembelajaran Fisika, Google Classroom, Kualitatif Deskriptif.

\begin{abstract}
The focus of this research is the situation of online learning Physics using Google Classroom. The research design used is descriptive qualitative. Respondents in this study were students and physics subject teachers at SMAN 1 Pedes. Data collection techniques include interviews and observations. The analysis technique is data reduction, data display and conclusion drawing. The results showed that the change in conventional physics learning methods in the form of face-to-face learning between teachers and students in the classroom which was carried out by presenting material, discussion, question and answer or practicum into an online method using Google Classroom had advantages and disadvantages felt by teachers and students. The advantages include that the teacher can use
\end{abstract}


Mahardini. - Analisis Situasi Penggunaan Google ...

various media for the learning process, both those contained in the Google Classroom or other media that can be linked to the classroom. While the drawbacks are network problems and the limited quota that students have can be an obstacle in the learning process, as well as the low level of activity of students in the learning process. In addition, the teacher felt that it was difficult to explain material that contained physical equations, students also had difficulty understanding the material which had an impact on the low ability of students to solve calculation problems.

Keywords: Online Learning, Physics Learning, Google Classroom, Qualitative Descriptive.

\section{PENDAHULUAN}

Pada akhir Desember 2019, dunia dikejutkan dengan berita adanya suatu penyakit yang gejalanya mirip dengan pneumonia yang penyebabnya belum diketahui. Infeksi pernapasan akut yang menyerang paru-paru itu terdeteksi di kota Wuhan, Provinsi Hubei, China. Sejak 3 Januari, China telah secara teratur memberi tahu WHO dan Negara-negara dan wilayah terkait seperti Hongkong, Macau, dan Taiwan tentang wabah pneumonia tersebut. Tanggal 12 Februari 2020, WHO resmi menetapkan penyakit dengan sebutan Coronavirus Disease (COVID-19). COVID-19 disebabkan oleh SARS-COV2 yang termasuk dalam keluarga besar coronavirus yang sama dengan penyebab SARS pada tahun 2003, hanya berbeda jenis virusnya.
Kasus covid-19 pertama di luar China dilaporkan di Thailand pada 13 Januari 2020, kemudian seiring berjalannya waktu, covid-19 ini menyebar ke Negara-negara di benua Asia, Eropa, Amerika, dan Afrika. Di Indonesia, kasus Covid-19 pertamakali diumumkan pada tanggal 2 Maret 2020. Kasus ini terjadi pada seorang ibu dan anaknya di wilayah kota Depok.

Berbagai kebijakan telah dikeluarkan oleh pemerintah Indonesia untuk mengurangi tingkat penyebaran virus corona dengan memberlakukan sosial distancing, physical distancing hingga pemberlakuan PSBB (pembatasan social berskala besar) pada beberapa daerah. Kebijakan-kebijakan yang dikeluarkan untuk membatasi penyebaran COVID-19 berdampak pada berbagai bidang diseluruh dunia 
Mahardini. - Analisis Situasi Penggunaan Google ...

khususnya pendidikan di Indonesia (Herliandry et al., 2020).

Hari Minggu, 15 Maret 2020, Gubernur Jawa Barat, Ridwan Kamil mengumumkan instruksi bagi seluruh pemerintah kabupaten kota untuk merumahkan seluruh siswa mulai PAUD hingga SMA/SMK dan melaksanakan kegiatan belajar mengajar di rumah, terhitung mulai 16 sampai 29 Maret 2020. Hal ini tentu saja pada awalnya membuat guru dan siswa kebingungan karena harus mengubah kebiasaan yang tadinya belajar itu di sekolah, di ruang kelas tiba-tiba harus melakukan kegiatan belajar mengajar dari rumah. Maka digunakanlah pembelajaran dengan metode online atau daring (dalam jaringan). Pembelajaran di rumah ini masih terus berjalan sampai hari ini seiring dengan belum meredanya kasus Covid-19 di Indonesia.

Dalam Herliandry et al, 2020,pembelajaran online didefinisikan sebagai pengalaman transfer pengetahuan menggunakan video, audio, gambar, komunikasi teks, perangkat lunak (Basilaia \& Kvavadze, 2020) dan dengan dukungan jaringan internet (Zhu \& Liu, 2020). Infrastruktur yang mendukung pembelajaran online secara gratis melalui berbagai ruang diskusi seperti Google Classroom, Whatsapp, Kelas Cerdas, Zenius, Quipper dan Microsoft 365 (Abidah et al., 2020).

Salah satu media pembelajaran yang dimanfaatkan oleh guru fisika SMA Negeri 1Pedes selama pandemi Covid-19 untuk belajar di rumah adalah memanfaatkan elearning dengan aplikasi yang digunakan berupa Google Classroom. Google Classroom (Ruang Kelas Google) adalah suatu aplikasi pembelajaran secara online yang dapat digunakan oleh semua lingkup pendidikan yang membantu guru dan siswa berbagi file dalam kegiatan belajar mengajar. Guru bisa membuat kelas mereka sendiri dan membagikan kode kelas tersebut atau mengundang para siswanya. Google Classroom menggabungkan Google Drive untuk pembuatan dan distribusi penugasan, Google Docs, Sheets, Slides untuk penulisan, Gmail untuk komunikasi, Google Calendar untuk penjadwalan, dan 
Mahardini. - Analisis Situasi Penggunaan Google ...

Google Meet untuk video itu, Basri (2014) menyimpulkan conference.

Untuk menggunakan Google Classroom, guru dan siswa dapat mengakses menggunakan dua cara, yaitu website dan aplikasi. Untuk website dapat diakses menggunakan browser apapun seperti Chrome, FireFox, ataupun Internet Explorer. Sedangkan untuk aplikasi dapat diunduh secara gratis melalui Playstore untuk Android dan App Store untuk iOS.

\section{METODE}

Desain penelitian yang digunakan dalam penulisan artikel ini adalah kualitatif deskriptif. Metode kualitatif berarti mengumpulkan data bukan berupa angka-angka, melainkan data tersebut berasal dari naskah wawancara, catatan lapangan, dokumen pribadi, maupun dokumen resmi lainnya.(Napsawati, 2020). Metode kualitatif lebih menekankan pada pengamatan fenomena dan lebih meneliti ke subtansi makna dari fenomena tersebut. Analisis dan ketajaman penelitian kualitatif sangat terpengaruh pada kekuatan kata dan kalimat yang digunakan. Oleh karena

bahwa fokus dari penelitian kualitatif adalah pada prosesnya dan pemaknaan hasilnya. Perhatian penelitian kualitatif lebih tertuju pada elemen manusia, objek, dan institusi, serta hubungan atau interaksi di antara elemen-elemen tersebut, dalam upaya memahami suatu peristiwa, perilaku, atau fenomena (Mohamed, Abdul Majid \& Ahmad, 2010).

Penelitian ini dilakukan di SMA Negeri 1 Pedes, Kabupaten Karawang, Provinsi Jawa Barat. Fokus dalam penelitian ini adalah sistem pembelajaran daring Fisika menggunakan Google Classroom. Informan dalam penelitian ini adalah peserta didik SMAN 1 Pedes (dipilih 20 orang tiap jenjang kelas untuk diwawancara ) dan dua orang guru mata pelajaran Fisika di SMAN 1 Pedes.

Pengumpulan data yang digunakan dalam penelitian ini adalah sebagai berikut:

Wawancara

Wawancara dilakukan dengan bertanya langsung kepada informan untuk menggali dan mendapatkan 
Mahardini. - Analisis Situasi Penggunaan Google ...

informasi mengenai situasi

pembelajaran daring fisika dengan

menggunakan Google Classroom .

Wawancara dengan informan

dilakukan secara online.

Observasi

Observasi adalah teknik pengumpulan data atau informasi dengan cara pengamatan terhadap kegiatan yang sedang berlangsung. Observasi dilakukan untuk memperoleh gambaran riil suatu peristiwa atau kejadian untuk menjawab pertanyaan penelitian.

Teknis analisis data yang digunakan dalam penelitian ini adalah sebagai berikut.

\section{Reduksi Data}

Reduksi data merupakan bentuk analisis yang menajamkan, menggolongkan, mengarahkan, membuang yang tidak perlu, dan mengorganisasikan data sehingga kesimpulan akhir dapat diambil.

Display Data

Dalam penelitian ini, data disajikan dalam bentuk bentuk teks naratif. Penyajian data diawali dengan memberikan deskripsi hasil penelitian. Setelah data melalui proses tersebut, kemudian dilakukan analisis dalam pembahasan.

Penarikan Kesimpulan

Langkah terakhir ialah penarikan kesimpulan dan verifikasi, setiap kesimpulan awal masih kesimpulan sementara yang akan berubah bila diperoleh data baru dalam pegumpulan data berikutnya. Kesimpulan-kesimpulan yang diperoleh selama dilapangan diverifikasi selama penelitian berlangsung dengan cara memikirkan kembali dan meninjau ulang catatan lapangan sehingga berbentuk penegasan kesimpulan.

\section{HASIL DAN PEMBAHASAN}

Berdasarkan hasil wawancara terhadap beberapa peserta didik dan 2 orang guru mata pelajaran fisika di SMAN 1 Pedes serta hasil observasi terkait penggunaan Google Classroom dalam pembelajaran daring mata pelajaran Fisika diperoleh hasil sebagai berikut.

Peserta didik SMAN 1 Pedes menyimpulkan bahwa google classroom baik yang berupa web ataupun aplikasi adalah platform yang mudah digunakan. 
Mahardini. - Analisis Situasi Penggunaan Google ...

Adapun kendala dari penggunaan google classroom antara lain peserta didik kurang memahami materi yang dibagikan oleh guru, terutama materi yang berupa hitungan. Selain itu, jaringan internet kadang kurang bersahabat sehingga peserta didik kurang optimal dalam mempelajari materi yang dibagikan oleh guru di classroom terutama materi berupa video, hal ini terjadi juga ketika harus mengupload tugas yang berupa foto atau video.

Banyak peserta didik yang tidak bisa mengikuti video conference dikarenakan terkendala kuota dan jaringan internet. Materi yang dibagikan di classroom tidak membuat memori HP cepat penuh. Peserta didik dengan motivasi belajar rendah cenderung melalaikan tugastugas yang diberikan oleh guru.

Peserta didik kesulitan mengatur waktu belajar karena banyaknya aktivitas lain yang harus dikerjakan di rumah. Dari 60 responden, 59 orang menyatakan lebih senang belajar di sekolah daripada di rumah, dan hanya 1 orang yang menyatakan bahwa belajar di rumah lebih menyenangkan.
Tanggapan guru mata pelajaran terhadap penggunaan google classroom antara lain mudah digunakan dan memiliki fitur-fitur yang memudahkan untuk membuat daftar hadir peserta didik, membagikan materi, memberi tugas dan memberikan nilai pada tugas tersebut.

Materi yang dibagikan di classroom dapat beragam, mulai dari file materi, video pembelajaran, dan dapat menambahkan link yang terhubung ke laman web ataupun youtube. Selain itu, google classroom tidak membuat memori HP penuh karena penyimpanannya berbasis cloud.

Guru kesulitan dalam menjelaskan materi-materi yang berisi persamaan fisika. Tingkat partisipasi peserta didik dalam Google Meet rendah. Banyak peserta didik yang terlambat mengisi daftar hadir dan menyerahkan tugas.

Masalah lain yang ditemui adalah beberapa peserta didik yang tidak pernah mengisi daftar hadir dan mengumpulkan tugas. Guru lebih menyukai pembelajaran langsung 
Mahardini. - Analisis Situasi Penggunaan Google ...

secara tatap muka di kelas daripada pembelajaran secara daring.

Berdasarkan hasil penelitian di atas, maka pembelajaran fisika secara daring dengan menggunakan Google Classroom ini mempunyai kelebihan dan kekurangan. Peserta didik dan guru sepakat jika google classroom ini mudah digunakan dan membantu proses belajar selama masa pandemi ini dan tidak membuat memori HP penuh karena semua yang dibagikan dalam classroom tersebut tersimpan dalam penyimpanan berbasis cloud.

Untuk pemberian materi, guru merasa kesulitan ketika harus membahas materi yang banyak terdapat persamaan fisika dan peserta didik pun merasa kesulitan dalam memahami materi tersebut, terutama untuk peserta didik kelas IPS yang mendapatkan pelajaran Lintas Minat Fisika. Hal ini mungkin dapat disiasati dengan membuat video pembelajaran yang berisikan guru yang sedang menjelaskan persamaan-persamaan fisika tersebut dan untuk penyampaian materi pun dipilih kompetensi-kompetensi esensial yang sekiranya lebih mudah dipahami peserta didik.

Situasi pembelajaran juga kadang-kadang kurang kondusif yang diakibatkan oleh berbagai faktor. Bermacamnya provider internet yang digunakan peserta didik yang masing-masing mempunyai perbedaan kekuatan jaringan internet dan juga keterbatasan kuota yang dimiliki oleh peserta didik menyebabkan proses pembelajaran tidak optimal, terutama ketika guru ingin proses pembelajaran menggunakan Google Meet.

Selanjutnya, karena peserta didik ada di rumah, maka ada aktivitasaktivitas lain yang biasanya tidak dilakukan ketika mereka belajar di sekolah. Misalnya saja membantu orang tua mengerjakan pekerjaan rumah, main game sampai larut malam sehingga bangun kesiangan, atau bahkan harus menjadi "guru" bagi adiknya yang juga harus belajar di rumah. Hal-hal tersebut bisa mengganggu kelancaran proses pembelajaran online seperti telat mengisi daftar hadir atau terlambat mengumpulkan tugas. Hal ini bisa diminimalisasi dengan menjalin 
Mahardini. - Analisis Situasi Penggunaan Google ...

komunikasi yang baik antara guru dan orangtua peserta didik. Orangtua peserta didik harus memahami bahwa anaknya memang ada di rumah tapi tetap harus mengikuti proses pembelajaran.

Berikutnya, ada beberapa peserta didik yang jarang bahkan tidak pernah mengisi daftar hadir maupun mengumpulkan tugas. Biasanya peserta didik ini adalah peserta didik dengan motivasi belajar yang rendah, bahkan di pembelajaran tatap muka di kelas pun peserta didik-peserta didik ini berperilaku serupa. Hal ini sudah dikomunikasikan kepada wali kelas dan guru bimbingan konseling untuk melakukan visitasi ke rumah peserta didik tersebut untuk mendapatkan informasi kendala apa yang menyebabkan peserta didik tersebut tidak mengerjakan tugas dan dicari solusinya bersama-sama.

Pada dasarnya, baik guru dan peserta didik lebih menyukai pembelajaran secara tatap muka di kelas daripada pembelajaran daring karena pembelajaran tatap muka dinilai lebih efektif dalam pemberian materi dan berkomunikasi, serta lebih jelas dalam pembagian waktu belajarnya.

\section{KESIMPULAN DAN SARAN}

Berdasarkan data dari responden di atas, perubahan metode pembelajaran fisika konvensional berupa tatap muka antara guru dengan peserta didik di kelas yang dilakukan dengan pemaparan materi, diskusi, tanya jawab ataupun praktikum menjadi metode daring menggunakan Google Classroom mempunyai kelebihan dan kekurangan yang dirasakan oleh guru maupun peserta didik.

Kelebihan dari penggunaan google classroom antara lain penguasaan IT guru dan siswa meningkat. Guru dapat menggunakan berbagai media untuk proses pembelajaran, baik yang terdapat dalam Google Classroom atau media lain yang bisa ditautkan pada classroom tersebut. Sedangkan kekurangannya yaitu permasalahan jaringan maupun keterbatasan kuota yang dimiliki peserta didik bisa menjadi penghambat dalam proses pembelajaran, pun begitu pula dengan rendahnya tingkat keaktifan 
Mahardini. - Analisis Situasi Penggunaan Google ...

peserta didik dalam proses pembelajaran. Selain itu, guru merasakan adanya kesulitan untuk menjelaskan materi yang terdapat persamaan-persamaan fisika, peserta didik pun mengalami kesulitan dalam memahami materi tersebut yang berdampak pada rendahnya kemampuan peserta didik menyelesaikan soal hitungan.

Dalam menghadapi kendala tersebut, sudah dicoba dilakukan pemberian materi dibatasi pada kompetensi-kompetensi dasar yang esensial dan dibuatkan suatu media pembelajaran dengan bahasa sederhana yang lebih mudah dipahami oleh peserta didik.

\section{DAFTAR PUSTAKA}

Awaluddin, Y. (2018). Efektivitas program guru pembelajar dalam peningkatan kompetensi guru IPS SMP dengan moda daring murni dan daring kombinasi: studi evaluatif dan komparatif. Jurnal Pendidikan Dan Kebudayaan, 3(1).

Suwardiyanto, D., \& Yuliandoko, H. (2017). Pemanfaatan Teknologi Sebagai Media Pembelajaran Daring (On Line) Bagi Guru Dan Siswa Di Smk $\mathrm{Nu}$ Rogojampi. J-Dinamika:
Jurnal Pengabdian Kepada Masyarakat, 2(2).

Harahap, A. C. P., Harahap, D. P., \& Harahap, S. R. (2020). Analisis Tingkat Stres Akademik Pada Mahasiswa Selama Pembelajaran Jarak Jauh Dimasa Covid-19. Biblio Couns: Jurnal Kajian Konseling dan Pendidikan, 3(1), 10-14.

Herliandry, L. D., Nurhasanah, N., Suban, M. E., \& Kuswanto, H. (2020). Pembelajaran Pada Masa Pandemi Covid-19. JTPJurnal Teknologi Pendidikan, 22(1), 65-70.

Lestari, S. W. (2020). Kendala Pelaksanaan Pembelajaran Jarak Jauh (Pjj) Dalam Masa Pandemi Ditinjau Dari Media Pembelajaran. Journal of Chemical Information and Modeling 53(9): 287.

Mulyadi, E. (2020). Online Physics Learning Via Whatsapp, Google Form, And Email In The Achievement Of Active Presence And Student Learning Outcomes. Ideguru: Jurnal Karya Ilmiah Guru, 5(1), 3441.

Mustakim, M. (2020). Efektivitas Pembelajaran Daring Menggunakan Media Online Selama Pandemi Covid-19 Pada Mata Pelajaran Matematika. Al asma: Journal of Islamic Education, 2(1), 112.

Napsawati, N. (2020). Analisis Situasi Pembelajaran Ipa Fisika Dengan Metode Daring Di Tengah Wabah Covid-19. 
Mahardini. - Analisis Situasi Penggunaan Google ...

Karst: jurnal pendidikan fisika dan terapannya, 3(1), 6-12

Permata, A., \& Bhakti, Y. B. (2020). Keefektifan Virtual Class dengan Google Classroom dalam Pembelajaran Fisika Dimasa Pandemi Covid-19. JIPFRI (Jurnal Inovasi Pendidikan Fisika Dan Riset Ilmiah), 4(1), 27-33.

Ratnawati, F. A. (2020). Strategies To Improve Student Learning Outcomes During Pandemic Via Google Classroom Application In The Subject Of
Work And Energy. ideguru: jurnal karya ilmiah guru, 5(1), 49-55.

Sadikin, A., \& Hamidah, A. (2020). Pembelajaran Daring di Tengah Wabah Covid-19. Biodik, 6(2), 214-224.

Sofyana, L., \& Rozaq, A. (2019). Pembelajaran Daring Kombinasi Berbasis Whatsapp pada Kelas Karyawan Prodi Teknik Informatika Universitas PGRI Madiun. Jurnal Nasional Pendidikan Teknik Informatika: JANAPATI, 8(1), 81-86. 